\title{
HLA Class II Antibody Measurement
}

National Cancer Institute

\section{Source}

National Cancer Institute. HLA Class II Antibody Measurement. NCI Thesaurus. Code C128965.

The determination of the amount of HLA class II antibody present in a sample. 